\title{
Underpinning EFL Students' Speaking Skill Through Affective and Social Language Learning Strategy at University in Indonesia
}

\author{
Fitra Pinandhita ${ }^{1}$, Gunarhadi ${ }^{2}$, Mohd. Hanafi bin Mohd Yasin ${ }^{3}$, Munawir Yusuf ${ }^{4}$
}

${ }^{1}$ Fakultas Keguruan dan Ilmu Pendidikan, Universitas Sebelas Maret Surakarta

${ }^{2}$ Fakultas Keguruan dan Ilmu Pendidikan, Universitas Sebelas Maret Surakarta

${ }^{3}$ Fakulti Pendidikan, Universiti Kebangsaan Malaysia

${ }^{4}$ Fakultas Keguruan dan Ilmu Pendidikan, Universitas Sebelas Maret Surakarta

*Corresponding author. Email: fitra.pinandhita@student.uns.ac.id; gunarhadi@fkip.uns.ac.id;

mhmy6365@ukm.edu.my; munawiryusuf@staff.uns.ac.id

\begin{abstract}
This study focuses on how students reveal the affective and social strategy. There were 27 students in the $6^{\text {th }}$ semester of English education study program at Universitas PGRI Madiun, Indonesia. The results show that the male is $22,2 \%$ and female is $77,8 \%$. The students' perspectives towards the affective strategy in motivating and reinforcing themselves to elevate and enhance their speaking skill through; -trying to love English, -watching movies without subtitle, -be yourself and be confident, -keep on learning, want to join an international program, reading a lot of articles and books in English, -trying to speak alone at home, -watching vlog in YouTube. The elaboration on the social strategy (in the classroom) to support their speaking skill through;-talking with them using English, -having a presentation I have to speak English, - asking my friends using English when we are talking in the class, -using English in daily conversations, -starting a conversation using the English language, -talking with the lecturer in English, -chatting in social media like WhatsApp in English for practicing, although it does not always use English, -inviting my friends who want to improve the skill of their speaking to make the discussion group.
\end{abstract}

Keywords: speaking skill, affective strategy, social strategy

\section{INTRODUCTION}

In the era of globalization and industry 4.0, young people should be able to face worldwide competition in knowledge and skill. A student at university as one of the young ages should be aware of and be provided with global communication skills. Being able to literate with technology and foreign languages is the need to have involved in globalization competition. English speaking skills as the requisite of being able to communicate with the global people might be the essential skill that should be Enlighted instead. English speaking skill is the key to have to get interaction with the international community.

Facing the education of the $21^{\text {st }}$ century, students' skills to communicate the English language well is one of the important performances. To be able to speak English well, students need to consider the difficult thing in conducting speaking English for some reason [1] First, speaking provides the multifaced four language skills to emerge in global communication [2]. Second, some psychological factors contribute to students' speaking skills such as; affective and social factors [3]. The emergence of the mastery of four language skills and affective social strategy make students should strengthen their speaking skill in the context of using the English language in the global relationship.

Students of the English education study program at Universitas PGRI Madiun, Indonesia are motivating to enhance their English-speaking skills to show their speaking performance. Reflectively, some feel good in using English as the medium of communication in the classroom, some are not. Those who are brave speaking English with English mates are influenced by some indicators such as; his/her motivation learning English, his/her environment which supports them to practice speaking English. Even though in fact, they also face some obstacles to produce some English dialogues and 
conversations with a person to person and a group. The curriculum messages that speaking fluently is a part of the student's competence achievement so that they are ready to become an English teacher in the future.

Based on the pre-observation which was gotten from my previous study, mentioning that student's speaking skill is influenced by many factors; internal and external factors. The internal factors are like; student's goal of studying English, the possessing of motivation, and student's enthusiasm to practice English. Moreover, the external factors are; the mates they have who support to study, the facility they have, the teachers they learn from. Those factors determine the process and progress of student's achievement in mastering speaking English as though. In the context of the way to achieve a great internal and external factor, we need a strategy to cover them designed as the affective and social strategy in English language learning.

Considerately, EFL Students in Indonesia have a different strategy to elevate and enhance their Englishspeaking skills. They might have an affective strategy that rises from their inner self and personal factors in which support their motivation and reinforcement. The motivation that they build might be various things; intrinsic and extrinsic motivation. The reinforcement also has some dynamic affords; like studying, learning, and experiencing in developing their speaking performance. Affect is considered broadly as the aspects of emotion, feeling, mood, or attitude which to some extent determine behavior. A broad understanding of the effect on language learning is important for at least two reasons. Attention to affective aspects can lead to more effective language learning [4] and [5]

The social strategy is influenced by students' environmental factors. This means that students can develop their English-speaking skills as if they are motivated by the Enlighted environment like; the English study group or community, the English learning society, and the friends who have the same vision towards learning English at university. The learning environment at Universitas PGRI Madiun, Indonesia has some facilities like; the learning corners, English speaking area, the English literature library, the language sources digital, and language research community. On the sides, some students think that these environments do not support them to enhance their English mastery.

As the candidate of an English language teacher, in this case, the student should be able to implement and maintain the speaking English skill while they are practicing teaching in front of the class even being an English teacher in the future [6].

\subsection{Research Question}

From the introduction above, we illustrate the problems of our study is that how students of English education study program at Universitas PGRI Madiun Indonesia use the strategy of affective and social to develop their speaking skill?

\subsection{Research Frameworks}

Some studies on the student's speaking skills have been elaborated by these writers who had the same research topic;[7];[8],[9]. Hashim defined that speaking skill is one of the skills highlighted in language learning. Despite that, it is considered as the most difficult skill to be mastered compared to other language skills such as listening, reading, or writing. Speaking performance by students is one of the skills highlighted in language learning. Then Kusnierek said that the highlighted in a study about the definition and the importance of speaking skill is to convey messages and information to other persons. Torky mentioned about two types of speaking that are a monologue and a dialogue. the speaking activity within oneself and dialogue which occurs between two persons or more than that. While monologue, the persons involved will most likely use their first language as they talk to their selves. On the other hand, when people interact and communicate in pairs or groups of people, they usually tend to speak in a language that they all can understand.

Some researches towards the language learning strategies have been portrayed by some authors who concerned on this study, such as;[10];[11];[12][13];[14]. Language learning strategy is designed as the students' action or tactic for self-directed in learning the English language to select the goal, the techniques, and the approach to achieve the English mastery. Those authors mentioned that there is two English language learning strategy called as an affective and social strategy. These strategies can dig up the students' information about the indicators and factors that influence them in achieving greatly English-speaking skills. To support the language learning strategy, we draw the figure that Adapted from Bandura's Social Learning Theory: 1971.

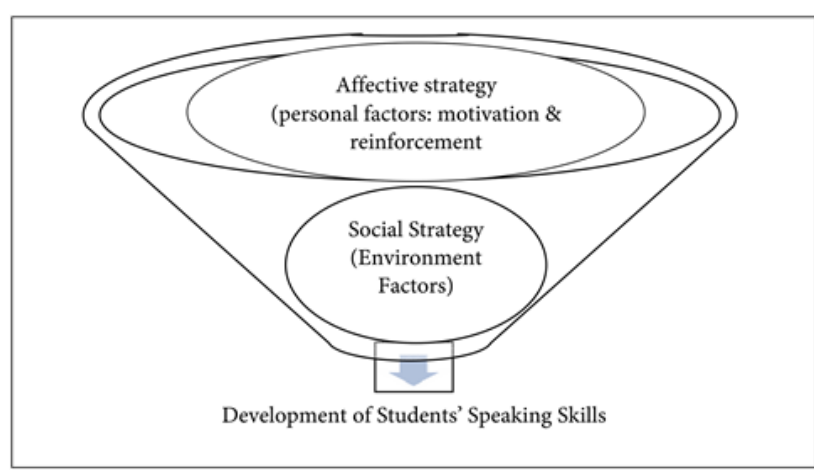

Figure 1. Conceptual Framework of the Language Strategies to Speaking Skills

Explaining the affective strategy have been explored by these following authors who focused on its strategy, 
such as; [15],[16],[17]. Mandasari \& Oktaviani Stated that "indicated effective strategy is the most suitable strategy to motivate students in learning the second language". Lavasani \& Faryadres declared that one of the affective factors is that student's motivation. it can be gained by diminishing the negative values in one selfesteem and create a positive habit to build the character as a good language learner whereby they can set up English speaking skills by themselves. Rossiter claimed that to help student's strength of English learning, they need an effective strategy to cope with their learning environment so that students can solve any obstacles which incoming while learning English by themselves. It is an important fact that contributes to the enhancement of students' speaking skills. The positive environment creates a positive impact on students. Thus, obstacles in language learning are easy to be alleviated.

Discussing on the social strategy have been revealed by these researchers who developed on it, such as; [18]mentioned that social strategy is one of the best language learning strategies to speaking skill. Students might practice speaking with their classmates or peers. Some students usually feel inferiors in practicing conversation since they do not need to have English rather than their native language, Indonesian language. By drilling and practicing their speaking skill with friends, they will be able to enhance their speaking skills as demanded by being an English teacher in the future. Also, [15] suggested that students should be able to maximize to collaborate and being active language learners. They can speak English fluently if they state the freedom of their belief in braving to speak English without any doubtfulness in grammar and sentence arrangement. [16] stated speaking skill cannot be empowered by itself, it needs the collaboration of other skills; listening, reading, and writing.

\section{RESEARCH METHODS}

\subsection{Research Design}

This is a qualitative research study that was conducted at the English education study program of Universitas PGRI Madiun, Indonesia. The participant of this study was those EFL students who study in the $6^{\text {th }}$ semester of English education study program. There is a consideration in stating that semester because I assume this is the period where students can be portrayed as their English-speaking skill on its competency. This study was done on April 9-10, 2020. I used the qualitative questionnaire by google form Microsoft to collect the data. To design the instrument, I referred to [15] and [18] to give a clue for participants. (see table 1)

I also set the number of questions to cope the answer of research questions dealing with digging up the students' language learning towards the affective and social strategy as the following; Questionnaire on
Research Instrument/Qualitative Data/ Direct InterviewDirect Participant

Table 1. The Clues of Questions on a Qualitative Questionnaire

\begin{tabular}{|c|c|}
\hline Speaking Skill & $\begin{array}{l}\text { is one of the skills } \\
\text { highlighted in language } \\
\text { learning }\end{array}$ \\
\hline \multirow{2}{*}{$\begin{array}{l}\text { Affective Strategy } \\
\text { (Personal Factors: } \\
\text { Motivation and } \\
\text { Reinforcement) }\end{array}$} & $\begin{array}{l}\text { is an indirect strategy of } \\
\text { the language learning } \\
\text { strategy (LLS)? }\end{array}$ \\
\hline & $\begin{array}{l}\text { Mandasari \& Oktaviani } \\
\text { (2018) indicated effective } \\
\text { strategy is the most suitable } \\
\text { strategy to motivate } \\
\text { students in learning the } \\
\text { second language/English as } \\
\text { Foreign Language }\end{array}$ \\
\hline \multirow[t]{2}{*}{$\begin{array}{l}\text { Social Strategy } \\
\text { (Environment } \\
\text { Factors) }\end{array}$} & $\begin{array}{l}\text { Hardan (2013) revealed } \\
\text { social strategy as one of the } \\
\text { best strategies in language } \\
\text { learning. }\end{array}$ \\
\hline & $\begin{array}{l}\text { Students can practice } \\
\text { speaking with their peers. } \\
\text { Some of the students are } \\
\text { having a lack of confidence } \\
\text { to speak in other languages } \\
\text { than their native language }\end{array}$ \\
\hline
\end{tabular}

List of Questions; 1) Name ...? 2) Gender ...? 3) Semester / class...? 4) Do you enjoy attending and joining the speaking class? If yes/not, give the why? 5) Do you want to improve your speaking skill? If yes/not, give the why? 6) Affective Strategy: How do you motivate yourself to elevate your speaking skill? 7) Affective Strategy: How do you reinforce yourself to enhance your speaking skill? 8) Social Strategy: how do you make your environment (in the classroom) to support your speaking skill? 9) Social Strategy: How do you create your environment (out classroom) to strengthen your speaking skill? 10) In your opinion, which one is more dominant supporting you to improve your speaking skill? Affective or social strategy?

I did a Qualitative data analysis by requiring a 5-step process: 1. preparing and organizing the data beyond the google drive. 2. Reviewing and exploring the data. 3 . Creating initial data codes. 4. Reviewing those codes and revising or combining them into findings driven. 5 . Presenting the findings of data into a descriptive research report.

\subsection{Result of the Research}

There are some findings that I need to elaborate in detail based on the question in the instruments I conducted. They are occupied in several tables and figures or charts. Table 02 is telling the participants of the research. Then table 03 is about students' perspectives 
towards joining and improving speaking skills. Table 04 . The affective strategy on motivating and reinforcing students' speaking skills. Table 05 . The social strategy in the classroom and out of the classroom to strengthen students' speaking skills. Figure 1. The gender of research participants. Figure 2. The semester/class of research participants. Figure 3. The statements of research participants on the enjoying speaking class. Figure 4. The statements of research participants on improving speaking skills. Figure 5. The statement of research participants on the predominant strategy.

Table 2 is about the participant in the study. There were 27 students as the participants of the research who answered and fulfilled the qualitative questionnaire. They are all from the $6^{\text {th }}$ semester students distributed in class A and B. By gender there are 21 female students and 6 males. It reflects that mostly female loves studying language and culture rather than scientific and engineering.

Table 2. The Participants of the Research

\begin{tabular}{|c|c|c|}
\hline Name & Gender & $\begin{array}{l}\text { Semester/ } \\
\text { Class }\end{array}$ \\
\hline Ayu Sri Wahyuni & Female & $6 \mathrm{~B}$ \\
\hline Yosita Niken Pratiwi & Female & $6 \mathrm{~B}$ \\
\hline Rijalul Fawaid & Male & $6 \mathrm{~A}$ \\
\hline Hanifa Humaira & Female & $6 \mathrm{~A}$ \\
\hline Firdaus Bintang Sakti & Male & $6 \mathrm{~A}$ \\
\hline $\begin{array}{l}\text { Crysmonei Recha } \\
\text { Aprillia }\end{array}$ & Female & $6 \mathrm{~A}$ \\
\hline $\begin{array}{l}\text { Ayuza Marthiasanti } \\
\text { Fitriyana } \\
\end{array}$ & Female & $6 \mathrm{~A}$ \\
\hline Jony Saputra & Male & $6 \mathrm{~A}$ \\
\hline Putri Indah Sari & Female & $6 \mathrm{~A}$ \\
\hline Ihsan Bima W.A & Male & $6 \mathrm{~A}$ \\
\hline Eldha Astriana & Female & $6 \mathrm{~A}$ \\
\hline $\begin{array}{l}\text { Marfianita Ayu Nur } \\
\text { Azizah }\end{array}$ & Female & $6 \mathrm{~B}$ \\
\hline $\begin{array}{l}\text { Deta Yuyun Eti Utami } \\
\text { Arisanjaya }\end{array}$ & Female & $6 \mathrm{~B}$ \\
\hline Fazlur Akbar Ghifari & Male & $6 \mathrm{~B}$ \\
\hline Tri Susanti & Female & $6 \mathrm{~A}$ \\
\hline Enggar surgawi & Female & $6 \mathrm{~A}$ \\
\hline $\begin{array}{l}\text { Addina Milatul } \\
\text { Kusniah }\end{array}$ & Female & $6 \mathrm{~B}$ \\
\hline $\begin{array}{l}\text { Elytia clara } \\
\text { puspaningrum }\end{array}$ & Female & $6 \mathrm{~A}$ \\
\hline Rinjanur & Female & $6 \mathrm{~A}$ \\
\hline Siti Ade Umaeroh & Female & $6 \mathrm{~A}$ \\
\hline Karinda Alifi Dianivera & Female & $6 \mathrm{~A}$ \\
\hline Aning Tri Rahayu & Female & $6 \mathrm{~B}$ \\
\hline Diana Putri & Female & $6 \mathrm{~B}$ \\
\hline Nawal Arofah & Female & $6 \mathrm{~B}$ \\
\hline Satriya bayu aji & Male & $6 B$ \\
\hline Anis Nurhanifah & Female & $6 \mathrm{~B}$ \\
\hline Nindya Cahya Gandhi & Female & $6 \mathrm{~B}$ \\
\hline
\end{tabular}

Table 3 is about the findings of students' perspectives towards joining and improving speaking skills. Speaking skill is one of the skills highlighted in language learning [20]. The skill is required as a mean of communication, to impart knowledge or information from one person to another. First is about students enjoy attending and joining the speaking class. 2 students did not enjoy the speaking class, and 25 students felt to enjoy it. Then students enjoy attending and joining the speaking class because these following; students: -love to talk in English, -think speaking English can enrich other skill, get new experience, -learn how to say in English, -enjoy and interesting, -can improve speaking skill, can practice and train communication. On the hand, the reasons why students want to improve their speaking skill because students: -want to be fluent in English, -can speak English better, -need mastering English for work, -think speaking English is the most important skill, -can communicate with foreigners, -raise the self-confidence, - can support being a teacher's candidate. Instead, 2 students did not enjoy the reasons; they are being nervous while speaking English and they have difficulty in having good pronunciation as well as grammar.

Table 3. The Students' Perspectives towards Joining and Improving Speaking Skills

\begin{tabular}{|c|c|c|c|}
\hline \multicolumn{4}{|l|}{ Do } \\
\hline \multicolumn{4}{|l|}{ you } \\
\hline \multicolumn{4}{|l|}{ enjoy } \\
\hline \multicolumn{4}{|l|}{$\begin{array}{l}\text { attend } \\
\text { ing }\end{array}$} \\
\hline and & & Do you & \\
\hline joinin & & want to & \\
\hline $\mathrm{g}$ the & & improve & \\
\hline speak & If yes/not, & your & if yes/not, \\
\hline ing & give the & speaking & give the \\
\hline class? & why? & skill? & why? \\
\hline
\end{tabular}

\begin{tabular}{|c|c|c|c|}
\hline Yes & $\begin{array}{l}\text { I love to } \\
\text { talk } \\
\text { especially } \\
\text { in English }\end{array}$ & Yes & $\begin{array}{l}\text { I want to } \\
\text { be fluent } \\
\text { in English } \\
\text { and I } \\
\text { want to } \\
\text { be able to } \\
\text { talk with } \\
\text { Native } \\
\text { clearly }\end{array}$ \\
\hline Yes & $\begin{array}{l}\text { Because in } \\
\text { speaking } \\
\text { class there } \\
\text { are many } \\
\text { activities, } \\
\text { students } \\
\text { become the } \\
\text { center of } \\
\text { the learning } \\
\text { so it is no } \\
\text { boring }\end{array}$ & Yes & $\begin{array}{l}\text { I can } \\
\text { speak } \\
\text { better } \\
\text { than I } \\
\text { was in } \\
\text { high } \\
\text { school }\end{array}$ \\
\hline
\end{tabular}




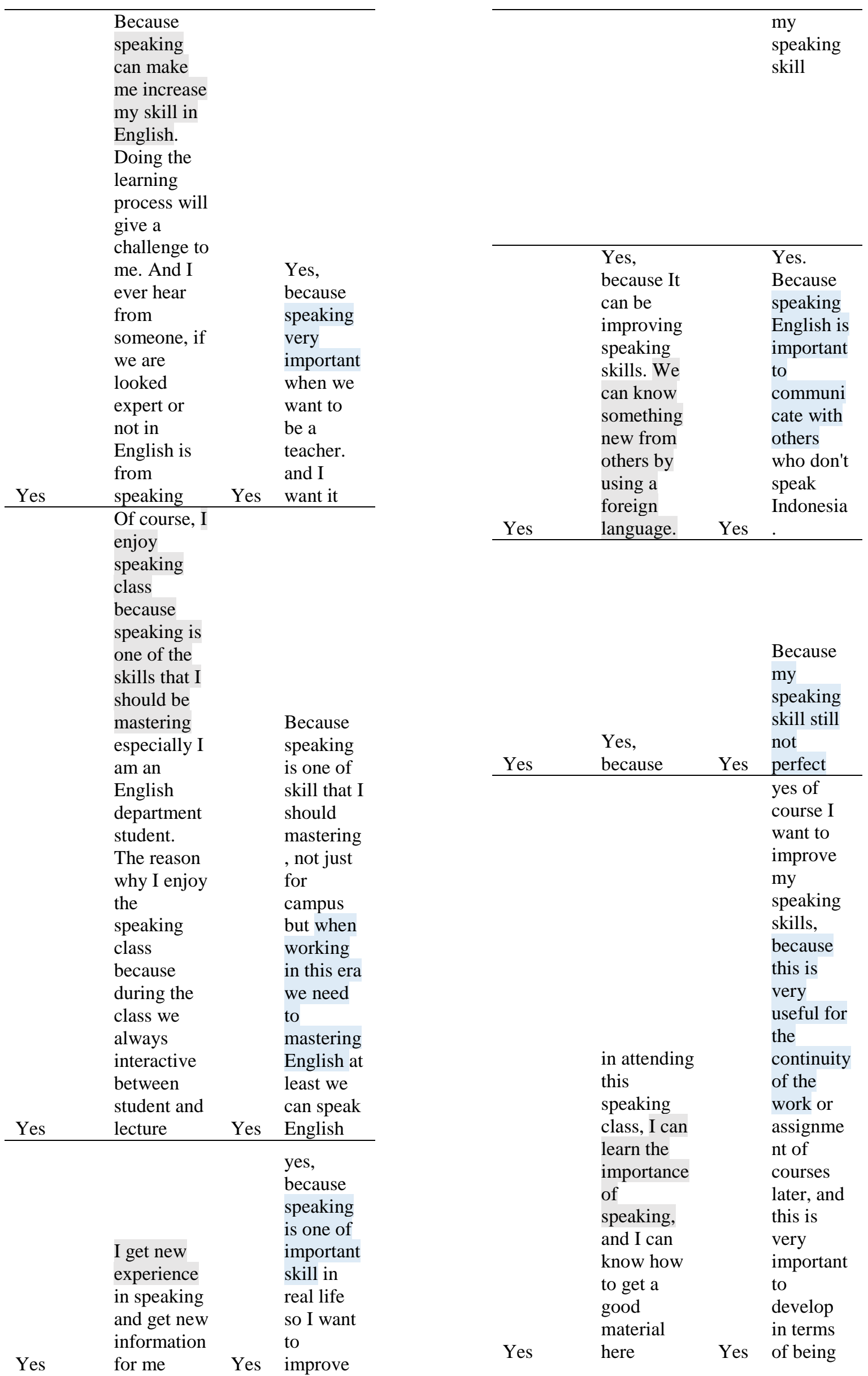




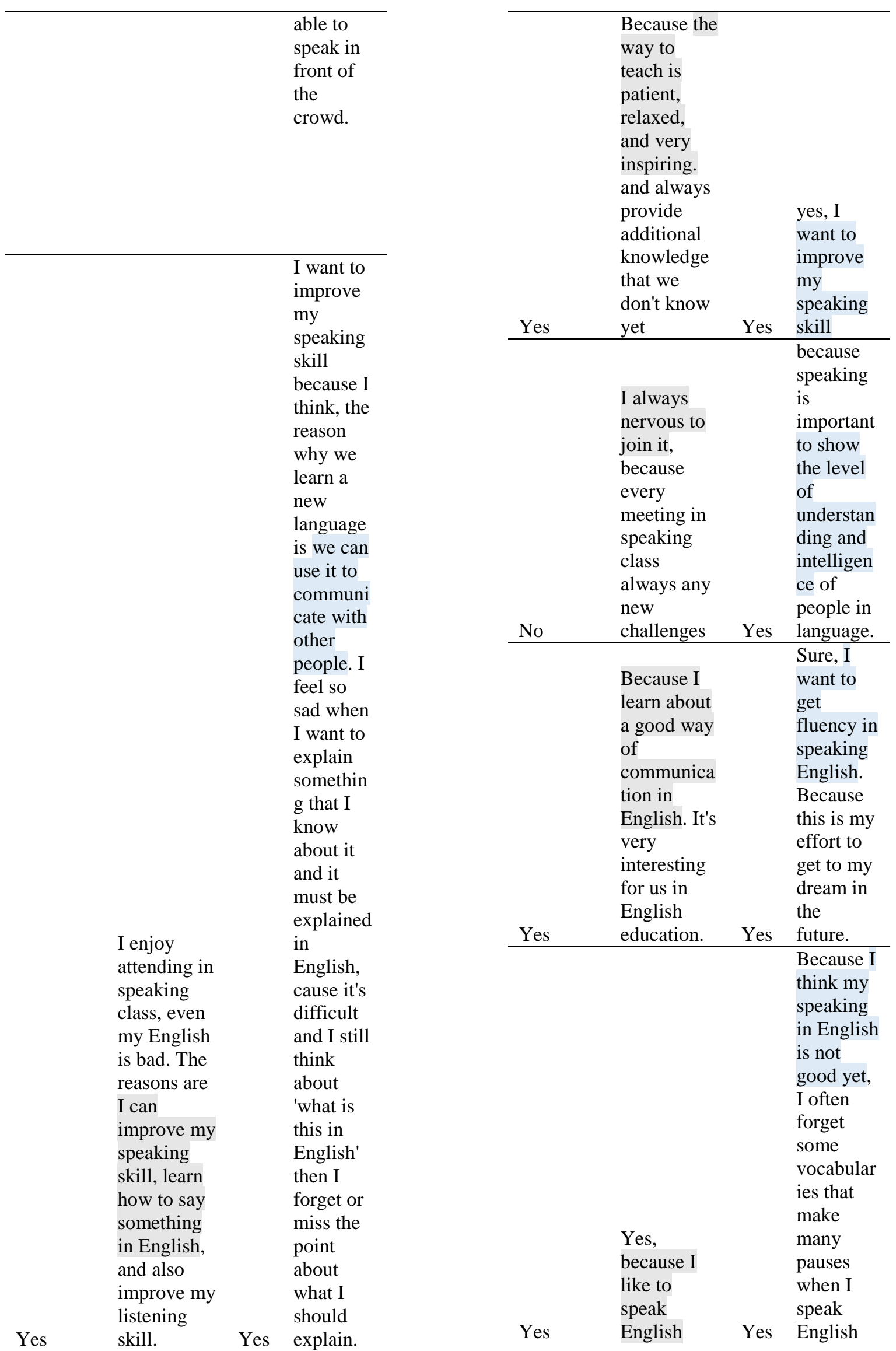




\begin{tabular}{|c|c|c|c|}
\hline Yes & $\begin{array}{l}\text { Yes, } \\
\text { because I } \\
\text { want to } \\
\text { improve my } \\
\text { speaking } \\
\text { skill again } \\
\text { and want to } \\
\text { know what } \\
\text { differences } \\
\text { between } \\
\text { British \& } \\
\text { American } \\
\text { speaking to } \\
\text { deep }\end{array}$ & Yes & $\begin{array}{l}\text { Yes, at } \\
\text { this } \\
\text { moment I } \\
\text { think my } \\
\text { speaking } \\
\text { skill is } \\
\text { not } \\
\text { enough } \\
\text { for } \\
\text { TOEFL } \\
\text { or another } \\
\text { test. And } \\
\text { my } \\
\text { speaking } \\
\text { skill is } \\
\text { badly to } \\
\text { much. }\end{array}$ \\
\hline Yes & $\begin{array}{l}\text { Because in } \\
\text { speaking } \\
\text { class I feel } \\
\text { enjoy and } \\
\text { very } \\
\text { interesting. }\end{array}$ & Yes & $\begin{array}{l}\text { my } \\
\text { speaking } \\
\text { skill is } \\
\text { not good } \\
\text { enough } \\
\text { because I } \\
\text { am } \\
\text { lacking } \\
\text { confidenc } \\
\text { e. }\end{array}$ \\
\hline Yes & $\begin{array}{l}\text { Speaking } \\
\text { class allows } \\
\text { me to } \\
\text { improve my } \\
\text { speaking } \\
\text { skill. }\end{array}$ & Yes & $\begin{array}{l}\text { By } \\
\text { mastering } \\
\text { the } \\
\text { speaking } \\
\text { skill, it } \\
\text { can help } \\
\text { me to } \\
\text { communi } \\
\text { cate with } \\
\text { other } \\
\text { people } \\
\text { from } \\
\text { foreign } \\
\text { countries. } \\
\text { As an } \\
\text { English } \\
\text { education } \\
\text { student, } \\
\text { speaking } \\
\text { skill is } \\
\text { required } \\
\text { to be } \\
\text { mastered } \\
\text { because it } \\
\text { will } \\
\text { support } \\
\text { me in the } \\
\text { future as } \\
\text { an } \\
\text { English } \\
\text { teacher. }\end{array}$ \\
\hline
\end{tabular}

\begin{tabular}{|c|c|c|c|}
\hline Yes & $\begin{array}{l}\text { because } \\
\text { with } \\
\text { speaking } \\
\text { class can } \\
\text { improve my } \\
\text { speaking } \\
\text { skill }\end{array}$ & Yes & $\begin{array}{l}\text { I feel my } \\
\text { skill in } \\
\text { speaking } \\
\text { have not } \\
\text { reached a } \\
\text { satisfying } \\
\text { level }\end{array}$ \\
\hline Yes & $\begin{array}{l}\text { Because it } \\
\text { can train } \\
\text { me to speak } \\
\text { up using } \\
\text { English to a } \\
\text { person/som } \\
\text { eone who } \\
\text { can only } \\
\text { speak } \\
\text { English, for } \\
\text { example } \\
\text { like tourists } \\
\text { and I can } \\
\text { teach } \\
\text { English to } \\
\text { elementary } \\
\text { school. }\end{array}$ & Yes & $\begin{array}{l}\text { Because I } \\
\text { want to } \\
\text { speak } \\
\text { English } \\
\text { sawist } \\
\text { and I } \\
\text { need to } \\
\text { reinforce } \\
\text { mu } \\
\text { speaking } \\
\text { skill }\end{array}$ \\
\hline Yes & $\begin{array}{l}\text { Because it } \\
\text { was fun and } \\
\text { so } \\
\text { important. }\end{array}$ & Yes & $\begin{array}{l}\text { Because } \\
\text { speaking } \\
\text { skills are } \\
\text { so } \\
\text { important } \\
\text { in the } \\
\text { future and } \\
\text { we need } \\
\text { to master } \\
\text { it. }\end{array}$ \\
\hline Yes & $\begin{array}{l}\text { I can learn } \\
\text { how to } \\
\text { speak well } \\
\text { and be } \\
\text { understood, } \\
\text { when in } \\
\text { public. } \\
\text { Make me to } \\
\text { confident to } \\
\text { speak up } \\
\text { with others. }\end{array}$ & Yes & $\begin{array}{l}\text { Of } \\
\text { course, } \\
\text { because } \\
\text { this study } \\
\text { is very } \\
\text { important } \\
\text { to be used } \\
\text { in or out } \\
\text { later. So } \\
\text { that I can } \\
\text { interact } \\
\text { better and } \\
\text { talk well } \\
\text { without } \\
\text { feeling } \\
\text { ashamed } \\
\text { and } \\
\text { studies } \\
\text { made me } \\
\text { speak up. } \\
\text { Because } \\
\text { there is a }\end{array}$ \\
\hline
\end{tabular}




\begin{tabular}{ll}
\hline way how \\
to speak \\
well.
\end{tabular}

\begin{tabular}{|c|c|c|c|}
\hline Yes & $\begin{array}{l}\text { I can speak } \\
\text { freely } \\
\text { without } \\
\text { thinking } \\
\text { about } \\
\text { grammar, } \\
\text { but if I used } \\
\text { incorrect } \\
\text { grammar } \\
\text { my lecture } \\
\text { will tell me } \\
\text { and give } \\
\text { the correct } \\
\text { grammar. }\end{array}$ & Yes & $\begin{array}{l}\text { Yes, } \\
\text { because } \\
\text { speaking } \\
\text { skill will } \\
\text { be useful } \\
\text { in the } \\
\text { future }\end{array}$ \\
\hline Yes & $\begin{array}{l}\text { Because } \\
\text { with a } \\
\text { speaking } \\
\text { class I can } \\
\text { improve my } \\
\text { speaking } \\
\text { skill. } \\
\text { Besides, } \\
\text { my class } \\
\text { was also in } \\
\text { a good } \\
\text { mood. }\end{array}$ & Yes & $\begin{array}{l}\text { Because I } \\
\text { want to } \\
\text { speak } \\
\text { English } \\
\text { fluently }\end{array}$ \\
\hline No & $\begin{array}{l}\text { Because my } \\
\text { speaking } \\
\text { was not } \\
\text { proficient } \\
\text { (especially } \\
\text { in } \\
\text { pronunciati } \\
\text { on and } \\
\text { grammar) }\end{array}$ & Yes & $\begin{array}{l}\text { Because } \\
\text { fluently } \\
\text { and } \\
\text { correctly } \\
\text { in } \\
\text { speaking } \\
\text { (started } \\
\text { from } \\
\text { pronuncia } \\
\text { tion and } \\
\text { grammar) } \\
\text { will be } \\
\text { more } \\
\text { comforta } \\
\text { ble in } \\
\text { every } \\
\text { context of } \\
\text { communi } \\
\text { cation } \\
\text { and will } \\
\text { understan } \\
\text { d the } \\
\text { situation }\end{array}$ \\
\hline
\end{tabular}

\begin{tabular}{ll}
\hline in the \\
context
\end{tabular}

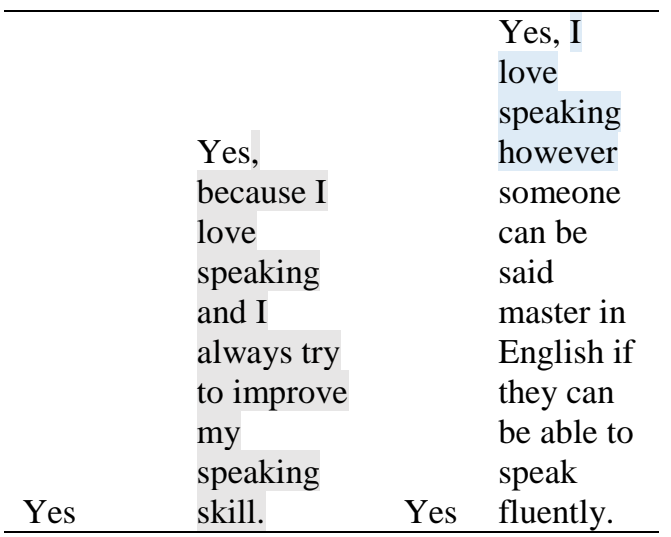

\begin{tabular}{|c|c|c|c|}
\hline Yes & $\begin{array}{l}\text { Yes, } \\
\text { because I } \\
\text { want to } \\
\text { improve my } \\
\text { speaking } \\
\text { skill }\end{array}$ & Yes & $\begin{array}{l}\text { Yes, } \\
\text { because I } \\
\text { want to } \\
\text { master } \\
\text { English } \\
\text { skill }\end{array}$ \\
\hline Yes & $\begin{array}{l}\text { Because } \\
\text { speaking is } \\
\text { one of } \\
\text { English } \\
\text { skill, and as } \\
\text { the college } \\
\text { student of } \\
\text { the } \\
\text { department } \\
\text { of English } \\
\text { teaching we } \\
\text { must afford } \\
\text { to all } \\
\text { English } \\
\text { skill }\end{array}$ & Yes & $\begin{array}{l}\text { Because } \\
\text { of all } \\
\text { English } \\
\text { skill, my } \\
\text { speaking } \\
\text { skill is } \\
\text { the worst. } \\
\text { I can't } \\
\text { speak } \\
\text { well in } \\
\text { front of } \\
\text { many }\end{array}$ \\
\hline
\end{tabular}

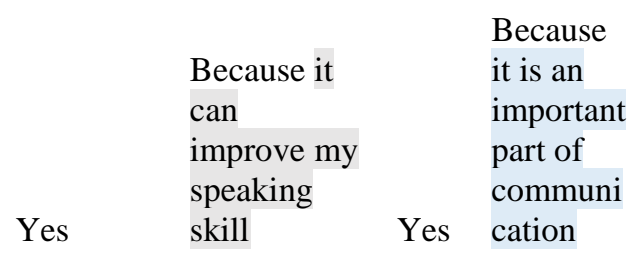


Table 4 tells us about the students' perspectives towards the affective strategy in motivating and reinforcing themselves to elevate and enhance their speaking skills. The affective strategy is an indirect strategy of the language learning strategy (LLS). [21] stated that the affective strategy is the most appropriate strategy to motivate students to learn the foreign language. Students will be able to engage with their feelings and reduce the difficulties they face by motivating themselves. The students' strategy to motivate themselves elevating their speaking skill by; usually watch American YouTube channel and listening to English songs, -trying to love English, -hoping become an English teacher, -watching movies without subtitle, be yourself and be confident, -keep on learning, -have friends have good English speaking, -want to join an international program, -have a friend native, -watch speech videos.

The students' strategy to reinforce themselves enhancing their speaking skill by; -singing English song every day to make my accent more fluent, -watching the movie and listening to the music in English, -trying with always speak English when I teach in Private and try to make a speech then I practice it, -being disciplined and consistent to learn to speak, -singing an English song, watching YouTube for gain our vocabulary and the most important is practice, -Reading English novel, -watching vlog in YouTube, -reading a lot of articles and books in English, -trying speaking alone at home, -and to remember a vocabulary.

Table 4. The Affective Strategy on Motivating and Reinforcing Students' Speaking Skill

\begin{tabular}{|c|c|}
\hline $\begin{array}{l}\text { Affective } \\
\text { Strategy: How } \\
\text { do you } \\
\text { motivate } \\
\text { yourself to } \\
\text { elevate your } \\
\text { speaking skill? }\end{array}$ & $\begin{array}{l}\text { Affective Strategy: } \\
\text { How do you reinforce } \\
\text { yourself to enhance } \\
\text { your speaking skill? }\end{array}$ \\
\hline $\begin{array}{l}\text { I usually watch } \\
\text { American } \\
\text { YouTube } \\
\text { channels and } \\
\text { listening to an } \\
\text { English song. } \\
\text { And I always } \\
\text { imagine that } \\
\text { someday I will } \\
\text { be there to talk } \\
\text { with them (the } \\
\text { natives) }\end{array}$ & $\begin{array}{l}\text { I sing an English song } \\
\text { every day to make my } \\
\text { accent more fluent. I } \\
\text { chat with my friend } \\
\text { using English because } \\
\text { for me it helps me a lot } \\
\text { to enrich my } \\
\text { vocabulary, and I } \\
\text { usually talk in English } \\
\text { with them. I also have } \\
\text { some foreign friends } \\
\text { and talking with them } \\
\text { via what's app call to } \\
\text { examine my speaking } \\
\text { skill. }\end{array}$ \\
\hline
\end{tabular}

\begin{tabular}{|c|c|}
\hline $\begin{array}{l}\text { I try to love } \\
\text { English }\end{array}$ & $\begin{array}{l}\text { I watch the movie and } \\
\text { listening to music in } \\
\text { English }\end{array}$ \\
\hline $\begin{array}{l}\text { I motivate } \\
\text { myself with } \\
\text { always } \\
\text { remember that } \\
\text { Someone who } \\
\text { capable of } \\
\text { English or not } \\
\text { is looked from } \\
\text { speaking. And I } \\
\text { want to be a } \\
\text { teacher, so I } \\
\text { have to } \\
\text { increase my } \\
\text { speaking skill. } \\
\text { that is my } \\
\text { weapons }\end{array}$ & $\begin{array}{l}\text { By trying with always } \\
\text { speak English when I } \\
\text { teach in Private and try } \\
\text { to make a speech then I } \\
\text { practice it. }\end{array}$ \\
\hline $\begin{array}{l}\text { I usually } \\
\text { motivate my } \\
\text { self by } \\
\text { watching } \\
\text { movies with } \\
\text { English } \\
\text { subtitles or } \\
\text { without } \\
\text { subtitles. When } \\
\text { I can } \\
\text { understand } \\
\text { what the movie } \\
\text { talks about mi } \\
\text { feeling proud } \\
\text { of my self and } \\
\text { want to try to } \\
\text { another movie } \\
\text { and do the } \\
\text { same thing as i } \\
\text { did }\end{array}$ & $\begin{array}{l}\text { First, I need to } \\
\text { discipline and } \\
\text { consistency to learn to } \\
\text { speak. Then I need to } \\
\text { keep practice to } \\
\text { improve my speaking } \\
\text { skill especially in } \\
\text { vocabulary }\end{array}$ \\
\hline $\begin{array}{l}\text { be yourself and } \\
\text { be confident, I } \\
\text { can do it }\end{array}$ & $\begin{array}{l}\text { by singing an English } \\
\text { song, watching } \\
\text { YouTube gain our } \\
\text { vocabulary and the } \\
\text { most important is } \\
\text { practice }\end{array}$ \\
\hline $\begin{array}{l}\text { If others can do } \\
\text { it, I should too }\end{array}$ & $\begin{array}{l}\text { Practice it every day } \\
\text { Listening music with } \\
\text { English lyric } \\
\text { Watching foreign } \\
\text { movie } \\
\text { Read English novel }\end{array}$ \\
\hline $\begin{array}{l}\text { I try to not shy } \\
\text { When I } \\
\text { speaking in } \\
\text { front of manly } \\
\text { people }\end{array}$ & $\begin{array}{l}\text { I try to speak in front } \\
\text { of my friends, then I } \\
\text { improve my speaking } \\
\text { skill and study more } \\
\text { for new vocabulary }\end{array}$ \\
\hline
\end{tabular}




\begin{tabular}{|c|c|}
\hline $\begin{array}{l}\text { to motivate } \\
\text { myself I often } \\
\text { see people who } \\
\text { are active in } \\
\text { talking in front } \\
\text { of people, and I } \\
\text { see what } \\
\text { techniques that } \\
\text { person uses, } \\
\text { and I often see } \\
\text { videos of } \\
\text { people making } \\
\text { speeches or } \\
\text { people who like } \\
\text { to make a } \\
\text { counter about } \\
\text { dealing directly } \\
\text { with others. }\end{array}$ & $\begin{array}{l}\text { in improving oneself to } \\
\text { speak, that is by } \\
\text { practicing little by little } \\
\text { even though it is } \\
\text { difficult, but it is still } \\
\text { done because of the } \\
\text { desire to master } \\
\text { speaking earlier, and } \\
\text { not tired of looking for } \\
\text { references that can } \\
\text { make self-motivation. }\end{array}$ \\
\hline $\begin{array}{l}\text { I don't know } \\
\text { how to } \\
\text { motivate } \\
\text { myself, but } \\
\text { when I must } \\
\text { speak English } \\
\text { especially in } \\
\text { the class, I } \\
\text { always think } \\
\text { that 'if you } \\
\text { have an } \\
\text { opinion, just } \\
\text { tell it. You } \\
\text { don't have } \\
\text { another } \\
\text { opportunity to } \\
\text { explain/express } \\
\text { it' }\end{array}$ & $\begin{array}{l}\text { During this time, I } \\
\text { learn English by } \\
\text { watching vlog on } \\
\text { YouTube } \\
\text {. I watch a non-native } \\
\text { speaker's vlog because } \\
\text { it was easier to } \\
\text { understand what they } \\
\text { said. Sometimes I } \\
\text { repeat what they said } \\
\text { and learn how they } \\
\text { pronounce it. }\end{array}$ \\
\hline $\begin{array}{l}\text { I learned a lot } \\
\text { from the } \\
\text { classes I } \\
\text { attended, from } \\
\text { the way it was } \\
\text { delivered in } \\
\text { front of people } \\
\text { to the use of } \\
\text { good and right } \\
\text { language }\end{array}$ & $\begin{array}{l}\text { I try to always pay } \\
\text { attention and read on } \\
\text { the internet how to } \\
\text { improve the way of } \\
\text { speaking }\end{array}$ \\
\hline $\begin{array}{l}\text { the way I } \\
\text { motivate } \\
\text { myself is that I } \\
\text { believe that I } \\
\text { can do that, I } \\
\text { keep learning } \\
\text { and I always } \\
\text { remember one } \\
\text { of my life } \\
\text { goals, which is } \\
\text { I want to study } \\
\text { at one of the } \\
\text { universities in } \\
\text { the UK. }\end{array}$ & $\begin{array}{l}\text { I read a lot of articles } \\
\text { and books in English, } \\
\text { listen to the news, and } \\
\text { talk shows on } \\
\text { YouTube. learn words } \\
\text { that I don't understand } \\
\text { yet. }\end{array}$ \\
\hline
\end{tabular}

\begin{tabular}{|c|c|}
\hline $\begin{array}{l}\text { I have } \\
\text { motivated to } \\
\text { elevate my } \\
\text { speaking } \\
\text { English } \\
\text { because it } \\
\text { needs for our } \\
\text { job vacancy, } \\
\text { skill in } \\
\text { communication } \\
\text { and if we want } \\
\text { to study abroad } \\
\text { is using English } \\
\text { well }\end{array}$ & $\begin{array}{l}\text { Today, I reinforce } \\
\text { speaking skills by } \\
\text { watching videos on } \\
\text { YouTube, podcasts, } \\
\text { also content English on } \\
\text { Instagram. }\end{array}$ \\
\hline $\begin{array}{l}\text { Because I } \\
\text { want to go } \\
\text { to overseas, } \\
\text { I must be } \\
\text { able to speak } \\
\text { English } \\
\text { fluently, as } \\
\text { the student } \\
\text { of English } \\
\text { department I } \\
\text { have to } \\
\text { master in } \\
\text { speaking }\end{array}$ & \\
\hline $\begin{array}{l}\text { English than } \\
\text { another } \\
\text { major, I } \\
\text { must be able } \\
\text { to show up } \\
\text { my speaking } \\
\text { in front of } \\
\text { all of people } \\
\text { or public. }\end{array}$ & $\begin{array}{l}\text { By always remember my } \\
\text { target to go overseas, and } \\
\text { also remember that I am } \\
\text { as the students of the } \\
\text { department of English } \\
\text { teaching, remember all of } \\
\text { my purposes, and don't be } \\
\text { useless during my study } \\
\text { in this department. }\end{array}$ \\
\hline $\begin{array}{l}\text { My self, } \\
\text { because I } \\
\text { conscious my } \\
\text { speaking skill } \\
\text { need to } \\
\text { improve at the } \\
\text { highest level. }\end{array}$ & $\begin{array}{l}\text { Practice every day with } \\
\text { trying speaking alone } \\
\text { at home, and to } \\
\text { remember a vocabulary }\end{array}$ \\
\hline $\begin{array}{l}\text { By encouraging } \\
\text { myself to be } \\
\text { like my friends } \\
\text { who have good } \\
\text { speaking. }\end{array}$ & $\begin{array}{l}\text { With watching } \\
\text { speaking videos and } \\
\text { also learn many new } \\
\text { vocabularies. }\end{array}$ \\
\hline $\begin{array}{l}\text { I always talk to } \\
\text { myself if I have } \\
\text { to elevate my } \\
\text { speaking skill if } \\
\text { I want to join } \\
\text { an international } \\
\text { program. }\end{array}$ & $\begin{array}{l}\text { Talking to myself with } \\
\text { a certain topic is one of } \\
\text { my ways to enhance } \\
\text { my speaking skill. } \\
\text { Reading some articles } \\
\text { and giving feedback } \\
\text { can help me to elevate } \\
\text { my speaking skill. }\end{array}$ \\
\hline
\end{tabular}




\begin{tabular}{|c|c|}
\hline $\begin{array}{l}\text { I usually see } \\
\text { someone who } \\
\text { smart speaks } \\
\text { English, which } \\
\text { she/he like a } \\
\text { Native Speaker, } \\
\text { whereas we } \\
\text { don't know } \\
\text { from where } \\
\text { her/his lives. }\end{array}$ & $\begin{array}{l}\text { I supposed to motivate } \\
\text { my self. That's I can } \\
\text { do it }\end{array}$ \\
\hline $\begin{array}{l}\text { I want to speak } \\
\text { using English } \\
\text { with tourists, } \\
\text { my lectures, } \\
\text { and my } \\
\text { students swift } \\
\text { so I can help } \\
\text { the tourists } \\
\text { when they ask } \\
\text { something to } \\
\text { me, I can speak } \\
\text { with my } \\
\text { lectures enjoy } \\
\text { like not } \\
\text { nervous and I } \\
\text { can be a good } \\
\text { teacher to my } \\
\text { students. }\end{array}$ & $\begin{array}{l}\text { With listening to } \\
\text { music, watch movies, } \\
\text { talk to my friends, my } \\
\text { lecturers also my } \\
\text { students with using } \\
\text { English and memory } \\
\text { the vocab that I don't } \\
\text { know the meaning, or } \\
\text { like searching for the } \\
\text { new vocab. }\end{array}$ \\
\hline $\begin{array}{l}\text { I have to try to } \\
\text { speak in } \\
\text { English no } \\
\text { matter how bad } \\
\text { my speaking } \\
\text { skill; I have to } \\
\text { try it every day. }\end{array}$ & practice every day. \\
\hline $\begin{array}{l}\text { If others can do } \\
\text { this. I certainly } \\
\text { can do it more. } \\
\text { Trying there } \\
\text { won't hurt if it's } \\
\text { done well. And } \\
\text { always ask how } \\
\text { about their } \\
\text { opinions. }\end{array}$ & $\begin{array}{l}\text { By readings books or } \\
\text { novels in English. }\end{array}$ \\
\hline $\begin{array}{l}\text { I compare } \\
\text { myself with my } \\
\text { friends who } \\
\text { speak English } \\
\text { fluently. So, I } \\
\text { can motivate } \\
\text { and challenge } \\
\text { myself to } \\
\text { improve my } \\
\text { speaking skill }\end{array}$ & $\begin{array}{l}\text { In the beginning, I } \\
\text { train my speaking skill } \\
\text { with my close friend. } \\
\text { We talk used the } \\
\text { English language. We } \\
\text { talk about what we } \\
\text { like, so it will be an } \\
\text { interesting } \\
\text { conversation }\end{array}$ \\
\hline $\begin{array}{l}\text { I love to speak } \\
\text { English and my } \\
\text { goal since } \\
\text { childhood has } \\
\text { been to speak } \\
\text { English. }\end{array}$ & $\begin{array}{l}\text { I usually speaking } \\
\text { combine English with } \\
\text { Indonesian. Even } \\
\text { though English is only } \\
\text { one word. Like }\end{array}$ \\
\hline
\end{tabular}

\begin{tabular}{|c|c|}
\hline & $\begin{array}{l}\text { listening to music or } \\
\text { movies in English }\end{array}$ \\
\hline $\begin{array}{l}\text { I watched } \\
\text { English movies } \\
\text { on TV, listen to } \\
\text { English music, } \\
\text { and see } \\
\text { YouTube } \\
\text { (about people } \\
\text { who were not } \\
\text { native speakers } \\
\text { or not from a } \\
\text { country whose } \\
\text { main language } \\
\text { used English } \\
\text { was good at } \\
\text { using English) }\end{array}$ & $\begin{array}{l}\text { Learn speaking lessons } \\
\text { that have been } \\
\text { discussed on Campus } \\
\text { and enter English } \\
\text { course (especially in } \\
\text { speaking and grammar) }\end{array}$ \\
\hline $\begin{array}{l}\text { Always } \\
\text { thinking } \\
\text { "speaking is } \\
\text { easy". I can do } \\
\text { that if I always } \\
\text { try to improve. }\end{array}$ & Practice everyday \\
\hline $\begin{array}{l}\text { Always learn } \\
\text { something till I } \\
\text { die }\end{array}$ & $\begin{array}{l}\text { Hearing the English } \\
\text { song then I sing too }\end{array}$ \\
\hline $\begin{array}{l}\text { By look at } \\
\text { other friends } \\
\text { who have the } \\
\text { good speaking } \\
\text { skill, then I will } \\
\text { feel "why } \\
\text { she/he can do } \\
\text { that but I can't" }\end{array}$ & $\begin{array}{l}\text { By practice choose, I } \\
\text { believe practice makes } \\
\text { perfect. }\end{array}$ \\
\hline $\begin{array}{l}\text { I usually watch } \\
\text { a video of the } \\
\text { speech }\end{array}$ & $\begin{array}{l}\text { I practice my speaking } \\
\text { skill with always } \\
\text { talking to my self in } \\
\text { English }\end{array}$ \\
\hline
\end{tabular}

Then table 5 gives us the elaboration on the social strategy. Another strategy that this study focuses on is the use of social strategies in developing the ability to speak. The social strategy was mentioned by [22] as another language learning strategy that can support and enrich the oral skills of elementary school students to relate to each other. Moreover, in the way students making social strategy in their environment (in the classroom) to support their speaking skill, such as these following by; talking with them using English, - watching the movie in English together and discuss with English, - having a presentation I have to speak English, - using English when we do teach learning in class, - making the practice like a game, - making my environment in the classroom more comfortable but still can understanding for my friends, - exchanging ideas or sharing with other people so that we can support each other what we lack or others 
face, - explaining something in Bahasa, our friends will warn us and said 'English please'. I think, this thing can support my speaking skill, - following my friends to create a conducive class, - asking my friend to teach me, - asking my friends using English when we are talking in the class, - using English in daily conversations, - starting a conversation using the English language, - Talking with the lecturer in English.

On the hand, the way students create their environment (out classroom) to strengthen their speaking skill by; speaking English but just a little like "yes, no, I, you, etc., -Trying to speak English in classroom and in daily activity, -having interested everything that written or spoken in English, - using an application on my phone to find friends from another country so we can do language exchange and learn from it, - chatting in social media like WhatsApp in English for practicing, although it is not always use English, - trying to speak more comfortable and not shy, - learning from each other, making that speaking English in classroom become a habit, - asking my friends if there are difficulties in order to create harmony in and outside the classroom, teaching them to use English, - trying to speak with my little brother in English, -inviting my friends who want to improve the skill of their speaking to make the discussion group, -having community with a same goal (mastering speaking skill), - sometimes visiting international seminar or activities, or everything related with English, -watching people talk with English.

Table 5. The Social Strategy in the Classroom and Out of the Classroom to Strengthen Students' Speaking Skill

\begin{tabular}{ll}
$\begin{array}{l}\text { Social Strategy: how } \\
\text { do you make your } \\
\text { environment (in the } \\
\text { classroom) to support } \\
\text { your speaking skill? }\end{array}$ & $\begin{array}{l}\text { Social Strategy: } \\
\text { How do you create } \\
\text { your environment } \\
\text { (out classroom) to } \\
\text { strengthen your } \\
\text { speaking skill? }\end{array}$ \\
\hline & $\begin{array}{l}\text { I speak English but } \\
\text { just a little like "yes, } \\
\text { no, I, you, etc." in the } \\
\text { middle of my talking, }\end{array}$ \\
& $\begin{array}{l}\text { it will make them } \\
\text { familiar with my } \\
\text { accent. }\end{array}$ \\
$\begin{array}{l}\text { I will talk with them } \\
\text { using English }\end{array}$ & $\begin{array}{l}\text { Try to speak English } \\
\text { in the classroom and } \\
\text { daily activity }\end{array}$ \\
\hline $\begin{array}{l}\text { Watch the movie in } \\
\text { English together and } \\
\text { discuss with English }\end{array}$ & $\begin{array}{l}\text { By interested in } \\
\text { everything that } \\
\text { written or spoken in }\end{array}$ \\
\hline & $\begin{array}{l}\text { English. They are like } \\
\text { brochures, }\end{array}$ \\
announcements I \\
Be aware to speak
\end{tabular}

With presentation. In my class always presented in English. So, when I explaining about something I need to use English

by using English when we do teach learning in class so the students will be familiar with English

Make the practice like a game

I Will make my environment in the classroom more comfortable but still can understanding for my friends

exchanging ideas or sharing with other people so that we can support each other what we lack or others face.

It feels so shy when I talk to my classmates in English. But during the class activity, the lectures said that we must explain our material(presentation) in English and we must answer/ask in English. Recently, those things are habits. So, when we explain something in Bahasa, our friends will warn us and said 'English please'. I think, this thing can support my speaking skill

I followed my friends to create a conducive class

I told my friend that I had a weakness in
Usually, I used application on my phone to find friends from another country so we can do language exchange and learn from it. But sometimes I used mix language with my friends for example like " iya-iya I know that" or "which is dia yang salah"

we can chat in social media like WhatsApp in English for practice, although it does not always use English that one is one of strategy for ourselves

Make the practice like a game

When I speak at outside, I Will try to speak more comfortable and not shy

learn from each other, because from here surely know where lies the mistakes that might need to be fixed in speaking or talking.

The answer is similar to the previous question. To create an environment that strengthens speaking skills, we must make that speaking English in the classroom become a habit. I always ask my friends if there are difficulties to create harmony in and outside the classroom by teaching them to use English, namely 
speaking skills and asked my friend to teach me, the way we speaking all the time.

Yes, of course. Because speaking will be a success if we often get some practice with others.

using English in gadgets, computers, and laptops.

Maybe with speaking all thing with English, especially in the day what we want

I try to speak with my little brother in English, even though he can't understand I just speak and then translate what I said, and $I$ join volunteer as ISHO team because there are many students exchange that can't speak Indonesia so I have to speak English

I try to speak English with them, so they will try to answer in English too, even they just answer in Bahasa, I try to answer in English

If a friend says something with English, I trying to answer it with English too. Sometimes, what do I think it's not relevant to what I speak. more often with them, I watch movies in English, and try to speak English with my friends in my class every day

I think it's difficult for me because not all to respond if I say something with English.

\section{CONCLUSION AND PEDAGOGICAL IMPLICATION}

We can conclude the points of this study with these statements; there is a gender of research participants which are male and females', students. The male participant is $22,2 \%$ and female are $77,8 \%$. The student's samples were the sixth-semester grade of the English education study program which was dominantly formed class 6A. Students predominantly $92,6 \%$ do attending and enjoying the speaking class, and $7,4 \%$ do not like attending and joining it. $100 \%$ of students agree about the hope of improving their speaking skills. The dominant language learning strategy which is claimed by students is the affective strategy which $51,9 \%$. It is in line with (O’Malley \& Valdez, 1996) stated that outside the class in practicing students' speaking skills exposures students' confidence in communicating using English rather than having usual in-class speaking practice.

The motivation and reinforcement of the affective strategy, students do; using the technology to support their English-speaking skills like; internet, vlog, youtube, movies; singing English songs; reading some English books. The in-classroom and out-classroom environments of the social strategy, students do; practicing to speak English by themselves; speaking English to friends; having English- speaking community. From the statements above, students feel that effective strategy. Students' opinions relating to the strategy that is more predominantly influenced them in gaining their speaking English skill is an effective strategy. They claim that motivation and reinforcement are motoring them to improve and enhance their speaking to be fluent and full of confidence.

The pedagogical implication that can be declared is; students need to maintain the motivation and reinforcement in having an effective strategy. They should do those strategies in discipline time and goals they want to achieve. On the other hand, students should create their social strategy in times while in the classroom and out of the classroom. They should do both strategy togetherness in their activity while learning English at the campus.

\section{REFERENCES}

[1] Louma, S. (2004). Assessing speaking. Ernst Klett Sprachen.

[2] Bygate, M. (2009). Teaching the spoken foreign language. In B. Seidlhofer \& K. Knapp (Eds.), Teaching the Spoken Foreign Language (pp.401438). Mouton de Gruyter.

[3] Aydin, B. (2001). A study of sources of foreign language anxiety in speaking and writing classess. Anadolu Üniversitesi Egitim Fakültesi Yayınlarl, 74.

[4] Yashima, T., Zenuk-Nishide, L., \& Shimizu, K. (2004). The influence of attitudes and affect on willingness to communicate and second language communication. Language Learning, 54(1), 119152.

[5] Dewaele, J. M. (2005). Investigating the psychological and emotional dimensions in instructed language learning: Obstacles and possibilities. The Modern Language Journal, 89(3), 367-380.

[6] de Saint Léger, D., \& Storch, N. (2009). Learners' perceptions and attitudes: implications for willingness to communicate in an L2 classroom. System, 37(2), 269-285.

[7] Hasim, H., Zakaria, N., \& Yunus, M. M. (2019). A review of affective strategy and social strategy in developing students' speaking skills. Creative Education, 10(12), 3082-3090. 
[8] Kusnerek, A. (2015). Developing students'speaking skills through role-play. World Scientific News, 7, 73-111.

[9] Torky, S. A. E. (2006). The effectiveness of a taskbased instruction program in developing the english language speaking skills of secondary stage students. online submission.

[10] Brown, H. D. (2002). Principles of language learning and teaching. Cambridge University Press.

[11] Cohen, A. D. (1998). The learners side of foreign language learning: Where do styles, strategies, and tasks meet?. International Review of Applied Linguistics in Language Teaching, 41(4), 279-291.

[12] O’Malley, J. M., \& Chamot, A. U. (1990). Learning strategies in second language acquisition. Cambridge university press.

[13] Oxford, R. (1990). Language learning strategies. New York, 3.

[14] Weden, A. L. (1995). Learner training in context: A knowledge-based approach. System, 23(2), 183194. https://doi.org/10.1016/0346-251X(95)00007$\underline{7}$

[15] Mandasari, B., \& Oktaviani, L. (2018). English language learning strategies: An exploratory study of management and engineering students. Premise: Journal of English Education, 7(2), 61-78. http://dx.doi.org/10.24127/pj.v7i2.1581

[16] Rusdin, N. M. (2018). Teachers readiness in implementing 21 st century learning. Nternational
Journal of Academic Research in Business and Social Sciences, 8(4), 12931306.https://doi.org/DOI: $\quad$ 10.6007/IJARBSS/v8i4/4270

[17] Lavasani, M. G., \& Faryadres, F. (2011). Language learning strategies and suggested model in adults processes of learning second language. ProcediaSocial and Behavioral Sciences, 15, 191-197. https://doi.org/10.1016/j.sbspro.2011.03.072

[18] Rossiter, J. A. (2003). Model-based predictive control: A practical approach. CRC Press.

[19] Hardan, A. A. (2013). Language learning strategies: A general overview. Procedia-Social and Behavioral Sciences, 106, 1712-1726. https://doi.org/10.1016/j.sbspro.2013.12.194

[20] Hashim, H. U., Yunus, M. M., \& Hashim, H. (2018). Language Learning Strategies Used by Adult Learners of Teaching English as a Second Language (TESL). TESOL International, 39.

[21] Mandasari, B., \& Oktaviani, L. (2018). English language learning strategies: an exploratory study of management and engineering students. premise: Journal of English Education and Applied Linguistics, $7, \quad 61-78$. https://doi.org/10.24127/pj.v7i2.1581

[22] Henriquez, T., Von, H., Pena, V., \& Llanquileo, E. A. (2017). The effects of memory and social strategies on oral production. Colombian Applied Linguistics Journal, 19, 209- 218. https://doi.org/10.14483/22487085.10535 